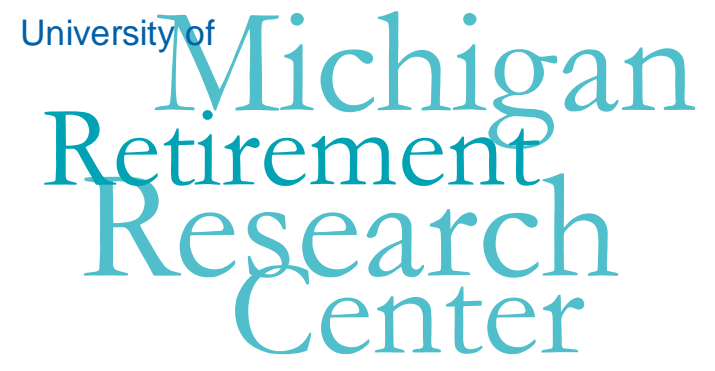

Working Paper

WP 2010-233

\title{
How Financial Literacy and Impatience Shape Retirement Wealth and Investment Behaviors
}

\author{
Justine Hastings and Olivia S. Mitchell
}

\begin{tabular}{|l|l|}
\hline $\mathrm{M}$ & $\mathrm{R}$ \\
\hline $\mathrm{R}$ & $\mathrm{C}$ \\
\hline
\end{tabular}

Project \#: UM10-11 


\title{
How Financial Literacy and Impatience Shape Retirement Wealth and Investment Behaviors
}

\author{
Justine Hastings \\ Brown University and NBER \\ Olivia S. Mitchell \\ The Wharton School and NBER \\ October 2010 \\ Michigan Retirement Research Center
University of Michigan
P.O. Box 1248
Ann Arbor, MI 48104
http://www.mrrc.isr.umich.edu/ \\ (734) 615-0422
}

\section{Acknowledgements}

This work was supported by a grant from the Social Security Administration through the Michigan Retirement Research Center (Grant \# 10-M-98362-5-01). The findings and conclusions expressed are solely those of the author and do not represent the views of the Social Security Administration, any agency of the Federal government, or the Michigan Retirement Research Center.

Regents of the University of Michigan

Julia Donovan Darrow, Ann Arbor; Laurence B. Deitch, Bingham Farms; Denise Ilitch, Bingham Farms; Olivia P. Maynard, Goodrich; Andrea Fischer Newman, Ann Arbor; Andrew C. Richner, Grosse Pointe Park; S. Martin Taylor, Gross Pointe Farms; Katherine E. White, Ann Arbor; Mary Sue Coleman, ex officio 


\title{
How Financial Literacy and Impatience Shape Retirement Wealth and Investment Behaviors
}

\begin{abstract}
Two competing explanations for why consumers have trouble with financial decisions are gaining momentum. One is that people are financially illiterate since they lack understanding of simple economic concepts and cannot carry out computations such as computing compound interest, which could cause them to make suboptimal financial decisions. A second is that impatience or present-bias might explain suboptimal financial decisions. That is, some people persistently choose immediate gratification instead of taking advantage of larger long-term payoffs. We use experimental evidence from Chile to explore how these factors appear related to poor financial decisions. Our results show that our measure of impatience is a strong predictor of wealth and investment in health. Financial literacy is also correlated with wealth though it appears to be a weaker predictor of sensitivity to framing in investment decisions. Policymakers interested in enhancing retirement well-being would do well to consider the importance of these factors.
\end{abstract}

\section{Authors’ Acknowledgements}

This research is part of the NBER programs on Aging and Labor Economics, and it was supported by a grant from the US Social Security Administration (SSA) to the Michigan Retirement Research Center (MRRC). Funding was also provided by the TIAA-CREF Institute, the Boettner Center/Pension Research Council at The Wharton School, the Yale Institution for Social and Policy Studies, and NIH/NIA grant AG023774-01, NIH/NIA Grant \# P30 AG12836, and NIH/NICHC Population Research Infrastructure Program R24 HD-044964, all at the University of Pennsylvania. Excellent research assistance was provided by Eric Chyn, Fabian Duarte, Raissa Fabregas, Peter Frerichs, Daniela Fuentes, Sarah Johnston, Carolina Orellana, José Luis Ruiz, and Javiera Vásquez. The authors thank David Bravo, Fabian Duarte, Raissa Faibregas, Peter Frerichs, Daniela Fuentes, Carolina Orellana, Sandra Quijada, and Javiera Vasquez for helpful comments. Opinions and errors are solely those of the authors and not of the institutions providing funding for or with which the authors are affiliated. (C)2010 Hastings and Mitchell. All rights reserved. 


\section{How Financial Literacy and Impatience Shape Retirement Wealth and Investment Behaviors}

Research and policy interest is increasingly focused on the links between financial literacy and household saving, seeking to explain why consumers seem to undersave for retirement, take on too much debt, make poor mortgage decisions, and experience other problems in the modern financial environment. ${ }^{1}$ This paper explores two explanations that have been offered for why consumers fail to optimize their financial decision making. One is that people suffer from financial illiteracy (Lusardi and Mitchell 2007a,b, 2008; Hastings and TejadaAshton 2008). This argument contends that many people lack the knowledge of key economic concepts and skills needed to make financial computations, which may cause them to make suboptimal financial decisions. It is this explanation that motivates the many policymakers who have recently launched campaigns to foster financial literacy around the world (OECD, nd; PACFL, 2008). A second explanation is that people are impatient or "present-biased," which implies that they chose current gratification over future, higher payoffs (Ashraf et al. 2006; Rabin and O’Donahue, 1999).

While both explanations could be influential in explaining apparently suboptimal saving and investment patterns, thus far there is little evidence that either of these behavioral limitations is at the root of poor financial decision making. This paper uses experimental evidence derived from the 2009 Chilean Encuesta de Protección Social (EPS or Social Protection Survey) to evaluate how financial literacy and impatience predict saving and investment decisions. The EPS

\footnotetext{
${ }^{1}$ See for instance Duarte and Hastings (2010), Abaluck and Gruber (2009), Ausubul (1991), Benartzi and Thaler (2001), Choi et al. (2006, 2007), Cronqvist and Thaler (2004); Hilgert et al (2003); Kling et al. (2008); Lusardi and Mitchell (2008, 2009, 2010); Lusardi and Tufano (2008); Madrian and Shea (2001); Ponce Rodriguez (2008); and Sirri and Tufano (1998).
} 
is similar to the US Health and Retirement Study, and it is a nationally representative panel of respondents followed every two years, fielded by the University of Chile's Microdata Center in cooperation with the University of Pennsylvania (c.f. Arenas et al. 2008; Mitchell et al. 2008). ${ }^{2}$ Chile is one of the most developed economies in Latin America, having levels of education and systems of credit similar to those of many developed countries. Also of interest is the fact that Chile converted to a mandatory national defined contribution system in 1981, giving all participating employees a chance to select a pension fund manager (AFP, or Pension Fund Administrator) from a small set of licensed portfolio managers. Two aspects of the 2009 EPS are particularly valuable for the present paper. First, we administered a battery of financial literacy questions (developed by Lusardi and Mitchell, 2007a,b) from which we develop a literacy index which can be used as a predictor of retirement saving and other key outcomes. Second, we designed and implemented a pair of experiments providing the opportunity to measure respondent impatience and respondent ability to carry out expressed intentions regarding financial behaviors, which we then link to outcomes of interest.

Our results show that our measure of impatience is a strong predictor of retirement saving and investment in health. Financial literacy is also correlated with accumulated retirement saving though it appears to be a weaker predictor of sensitivity to framing in investment decisions. These results have implications for policymakers interested in enhancing retirement well-being through addressing shortcomings in behavior and economic decision making that may hinder planning, decision making and investments for long-run financial and physical health.

\footnotetext{
${ }^{2}$ An earlier version of part of this discussion appears in Hastings, Mitchell, and Chyn (2010).
} 


\section{Data and Experimental Methodology}

The EPS is a nationally representative bi-annual microeconomic panel of Chileans, fielded by the University of Chile's Microdata Center in cooperation with the University of Pennsylvania (Arenas et al. 2008; Bravo et al. 2004, 2006; Mitchell et al. 2008). The 2009 wave of the EPS collected survey data for a little over 14,000 respondents included in the ten-year panel. The survey is similar to the US Health and Retirement Study, and it delves into respondents' labor history, health, retirement saving, and knowledge of and participation in Chile’s defined contribution old-age saving scheme. In addition, the EPS also asks respondents to answer several questions measuring financial literacy and risk preferences (devised by Lusardi and Mitchell 2007a, b). These questions are as follows:

1. Chance of Disease: If the chance of catching an illness is 10 percent, how many people out of 1000 would get the illness?

2. Lottery Division: If five people share winning lottery tickets and the total prize is two million Chilean pesos, how much would each receive?

3. Numeracy in Investment Context: Assume that you have $\$ 100$ in a savings account and the interest rate you earn on this money is 2 percent a year. If you keep this money in the account for five years, how much would you have after five years? Choose one: more than $\$ 102$, exactly $\$ 102$ or less than $\$ 102$.

4. Compound Interest: Assume that you have $\$ 200$ in a savings account, and the interest rate that you earn on these savings is 10 percent a year. How much would you have in the account after 2 years?

5. Inflation: Assume that you have $\$ 100$ in a savings account and the interest rate that you earn on these savings is 1 percent a year. Inflation is 2 percent a year. After one year, if you withdraw the money from the savings account you could buy more/less/the same?

6. Risk Diversification: Buying shares in one company is less risky than buying shares from many different companies with the same money. True/False

We use the responses to these questions to generate a financial literacy index - the sum of correct responses to each question ${ }^{3}$ - which is our measure of an individual's knowledge and capability of performing calculations needed to make wise financial decisions. ${ }^{4}$

\footnotetext{
${ }^{3}$ Behrman et al. (2010) explore alternative ways to construct a financial literacy index and report that more sophisticated measures perform about as well as the simple additive approach.
} 
To ascertain whether financial literacy affects how consumers understand financial terminology such as pension fund management fees and interest rates (following Hastings and Tejeda-Ashton, 2008), we provide information to individuals on pension investment returns net of fees, in various formats. Specifically, we present the pension fund menu in expected pension fund gains versus pension fund costs over a 10-year period, and we also vary whether these are presented in Chilean pesos or in Annual Percentage Rates. The formats were randomly assigned to EPS respondents, who were then asked to analyze the information and rank the funds on the menu as first, second, and third best, based on the information provided. We then use the financial literacy index discussed above to test whether the financially literate respondents are less strongly influenced by how the pension information is framed.

In a second experiment we investigate whether people subject to impatience -- that is, those who overweight current consumption versus the future - are also those who make shortsighted investment decisions. To test this hypothesis, at the end of the survey, each EPS participant was asked to play an "Investment Game" for a gift card. In return for filling out a short consumption questionnaire, the interviewer gave each participant a gift card to be used at the largest grocery chain in the nation. If the respondent completed the short questionnaire right away ('Now'), he would immediately receive a 5,000 peso gift card (about US\$8); alternatively, he could elect to do so 'Later' - i.e., fill out the questionnaire and mail it back in a pre-paid, addressed envelope within four weeks - at which time the gift card is activated with a higher amount. This higher amount was randomized between 6,000-8,000 pesos in 500 peso increments, so respondents who delayed would receive a 20-60 percent return if they delayed receipt (by up

\footnotetext{
${ }^{4}$ Arenas et al. (2008) describes other EPS responses regarding knowledge of the Chilean retirement system including the mandatory contribution rate, the legal retirement age for women (60) and men (65), how pension benefits are computed in the defined contribution system, whether people are aware of the welfare benefit available under the law, and whether people know they may contribute additional funds to the Voluntary Pension system. Mitchell et al. (2008) focus on pension switching in the EPS.
} 
to four weeks). ${ }^{5}$ The experiment permits us to identify three different types of respondents: the impatient who took the lower gift-card amount immediately, the efficacious deferrers who chose the later amount and returned the survey for the higher amount, and the inefficacious deferrers who opted for the later higher amount but then failed to send in the questionnaire so as to activate their cards. This provides a real-world decision measure of ability to delay current gratification for future gains, as well as evidence on peoples' ability to follow through on a plan with financial implications. Then we can determine whether respondents who choose Now at a cost of more money Later are also those who are unable to save for retirement and less likely to invest in their health.

\section{How Financial Literacy and Impatience Shape Retirement Wealth and Health}

In this section we explore how financial literacy and impatience are associated with retirement wealth and health. Table 1 reports summary statistics for the total number of financial literacy questions answered correctly, arrayed by respondent characteristics including age, sex, education, income, and whether the respondent indicated he had any saving. On average, younger individuals and men were more likely to give correct answers to more of the financial literacy questions. Similarly, financial literacy rises strongly with education levels, with those getting over half of the questions correct being more likely to have completed at least their secondary schooling. Average monthly income was also strongly positively correlated with financial literacy, as was the propensity to have some form of saving and to be a member of an

\footnotetext{
${ }^{5}$ Importantly, because the EPS is a longitudinal panel, all respondents have prior experience with the EPS interviewers, are regularly contacted by them for scheduling the interviews, receive a telephone number to easily contact the University of Chile's Microdatos Center if they have questions, and will be recontacted to respond to future waves of the EPS. Accordingly, the level of trust between respondents and the EPS is very high, which minimizes uncertainty regarding receiving the higher but delayed gift card amount.
} 
AFP pension plan (in the past, participation was optional for the self-employed and those not in formal sector jobs).

\section{Table 1 here}

Next we focus only on AFP participants (self-identified) and investigate how respondents performed on specific financial literacy questions. Table 2 shows that those who answered each question correctly were more likely than those who did not know the correct answers to have higher monthly income, more education, and saving. Of particular interest is the Compound Interest question. It asked respondents to calculate the exact amount they would have in a saving account after two years if they started with $\$ 200$ and the account paid 10 percent interest annually. Very few - only 154 respondents out of more than 8,000 asked the question answered it correctly by giving a response of \$242. This handful of respondents was substantially wealthier and more educated than the sample as a whole.

\section{Table 2 here}

Results from the Investment Game appear in Table 3. Overall, of the 8,850 participants in the investment game, ${ }^{6} 54 \%$ chose the Now option, with the remainder electing to turn it in Later for a higher value gift card. Of the latter, $17 \%$ failed to return the questionnaire, in effect losing the certain 5,000 pesos offered to begin with; 30\% successfully returned the survey and received the higher Later amount. Column 1 of Table 4 reports odds ratios of characteristics influencing the likelihood that a respondent chose Now versus Later for completing the short additional questionnaire. The odds of choosing Now decline with income, and the rate is lowest for those having the highest level of income (the excluded group is those earning 0). In addition, more educated respondents are much less likely to choose Now (the excluded education group is those with incomplete basic education). In fact, among those with post-secondary education at

\footnotetext{
${ }^{6}$ We excluded participants who lived in remote rural areas and thus could not make use of the grocery gift card.
} 
Technical or University levels, the odds of choosing Now decrease by about $40 \%$. Married couples are also less likely to choose Now, conditioning on age. Interestingly a higher financial literacy score also decreases the odds of choosing Now instead of Later. The effect is small, with a 1 point increase in the score associated with a $2.8 \%$ decrease in the odds of choosing Now. However, it suggests that those who choose to defer payment for a greater reward are more likely to possess a basic understanding of simple math and financial concepts necessary to make intertemporal financial decisions. We also find that the probability of selecting Later rises as the amount offered increases, not surprisingly. It is unexpected that a sizable fraction of participants still chose the Now option when the Later choice would pay 8000 pesos.

Table 3 here

The second column of Table 4 shows the effect that these characteristics have on efficacious deferrals - that is, being able to return the completed questionnaire and receive the higher gift card amount, conditional on choosing to complete the survey later. Interestingly, few of the sociodemographic variables predict this behavior, and the only strong and consistent factor refers to the respondent's unemployment status: being jobless boosts the odds of returning the survey successfully by nearly $50 \%$.

Next, we seek to understand how these factors might influence saving and investment outcomes, and also whether they play a role in addition to the influence of income and education. Accordingly, Table 5 illustrates how these factors influence reported measures of retirement saving. The first column presents odds ratios from a Logit model for self-reported participation in the additional AFP voluntary saving program into which covered workers may contribute if they wish (above and beyond the required 10\% contribution they are required to save in their mandatory AFP). Interestingly, choosing the Now option in the Investment Game is a 
significant predictor of whether the respondent says he contributes additional amounts to his personal pension account, and this estimate is in the expected direction: those who select Now have $25 \%$ lower odds of making voluntary contributions. Higher paid workers are more likely to contribute, though more educated participants are not. In addition, those with a higher financial literacy score are not more likely to pay in additional voluntary pension contributions, perhaps because they are saving in other vehicles.

\section{Table 4 here}

The second column of Table 5 provides Tobit estimates of self-reported savings regressed on the same set of variables. Here we see that those who chose Now in the game also have less saving. ${ }^{7}$ Financial literacy is also significant and positive - those with higher financial literacy scores are more likely to have higher saving accumulations (confirming Behrman et al., 2010). Comparing the impact of financial literacy versus choosing Now versus Later, impatience in the Investment Game lowers saving as much as a 2.5 point reduction in the financial literacy score. In other words, this provides support for the hypothesis that both financial literacy and short-run impatience play important roles in determining retirement saving, even after controlling for education and income.

Next we explore other ways in which these two factors shape peoples' long-term investment patterns. Tables 6 and 7 examine the relationship between measured health investments and behaviors and EPS participant choices in the Investment Game (health behaviors in the EPS are self-reported). One set of outcomes is whether respondents had had any of several preventative exams in the past two years (since the last EPS round) including Pap smear, breast exam, prostate exam, and general physicals. The first four columns of Table 6

\footnotetext{
${ }^{7}$ In future work we will include more complete measures of saving such as home equity and business capital, and net out debt (as in Behrman et al., 2010).
} 
show that performance in the Investment Game is a very strong predictor of having had preventative health exams for women. For them, people choosing Now are significantly less likely to have had Pap Smears and breast exams (odds fall by 22-35\%). Interestingly, higher educated women are much more likely to have breast exams but not Pap Smears, and generally income is not a strong predictor of either exam (perhaps the latter can be explained by the fact that Chile has a national health insurance scheme making the coverage widely available). For men, the likelihood of having had a prostate exam is uncorrelated with Investment Game behavior, though having had a general physical is. Here those who chose Later and followed through were significantly more likely to have had a general physical than either those who chose Now or those who chose Later and did not follow through.

Lastly, exercise can be viewed as a preventative health measure that imposes a cost now for health gains in the future. The EPS asks respondents approximately how often they exercise, with response options varying from never, to once or twice a month, to more than five times per week. We use this variable to construct a measure of weekly exercise habits to examine if we find a similar relationship between Investment Game responses and health investments as we did with prior outcomes. We do not find a significant relationship between self-reported exercise and Investment Game responses, even though the exercise measure is strongly influenced by education, age, marital status and sex with the signs and magnitudes one would expect.

\section{Tables 6 and 7 here}

Next we use respondent self-reported height and weight to construct a Body Mass Index to categorize each individual as underweight, normal weight, overweight, or obese. Results are provided in Table 7 for a Logit regression of whether the respondent is overweight or obese is related to performance in the Investment Game. For women, demographic factors and the 
Investment Gain patterns are strongly associated with weight. Specifically, both those who chose Now and those who chose Later and followed through with their investment are significantly less likely to be overweight - by about $20 \%$ - compared to those who naively chose Later but then failed to get their questionnaire in on time. Little except marital status affects weight for men.

For many people, then, behavior in the Investment Game is related to successful outcomes in retirement saving accumulations, as well as in health behaviors and health investments. This suggests that the Investment Game discriminates who is efficaciously patient those who can make forward-looking financial plans and follow through. We believe that identifying who has difficulty making such commitments may be important for increasing saving and investment behavior.

\section{Financial Literacy and Sensitivity to Information Framing}

We also undertook a separate experiment to further analyze how financial literacy might influence investment decisions. Since financial literacy is meant to measure the capacity and knowledge base necessary to perform calculations needed to make wise financial decisions, we hypothesize that financially illiterate individuals will be more sensitive to information and how financial information is framed. To examine this further, we provide individually-tailored account balance figures ${ }^{8}$ to respondents receiving the Gain version of the fee information worksheet used in the experiment. To construct the Loss version of worksheets, we compute the difference between the largest 10-year account balance for each individual and each of the other four AFPs in the menu. After fielding these experimental worksheets, we matched each

\footnotetext{
${ }^{8}$ Because some fund fees vary with contribution amounts, these valuations must be tailored to each respondent's own particulars. We created each person's estimated anticipated 10-year fund balances net of fees for all possible AFPs on offer by combining each respondent's earnings from the 2006 EPS with historical returns and fees data for each fund manager.
} 
respondent's top three AFPs they would 'recommend to a friend' to our own ranking of the AFPs for that individual.

Results appear in Table 8. Of the participants who received this information, 10 percent more respondents who saw the Gain sheet elected the lowest-cost AFP, versus those receiving the loss sheet (53 versus 48 percentage points). In general, people seem more responsive to rewards versus losses. Table 8 also indicates that the more educated, men, and the higher earners are more likely to elect the lowest-cost AFP, particularly when shown the Gain sheet.

Table 8 here

We further examine how information framing and other factors affect fund choice by testing for interaction effects of framing and literacy, so we can evaluate which population subgroups are most sensitive to information framing. Table 9 reports Logit odds ratios from analyses of whether respondents selected their lowest-cost AFPs, as a function of whether they received the Gain or Loss worksheet (controlling on other factors). The first column pools results across respondents given AFP information as either a Gain or a Loss; here we see that providing the Gain sheet is very powerful, boosting the odds of choosing the most profitable AFP by 26 percentage points. Quantitatively, showing participants a Gain worksheet has an impact as large as the impact of having a post-secondary education and twice as large as the impact of having above-median income. The measured effect is about the same as the impact of a one unit increase in the financial literacy index.

\section{Table 9 here}

In the second column, we add an interaction between financial literacy and how the information was framed. Now the odds ratio is significant and less than one, implying that a oneunit increase in the financial literacy index reduces the impact of information framing by 
approximately 10 percentage points. Next, we add an interaction between framing and an indicator if the person chose Now in the Investment Game. We do not find a significant impact, as expected. We would expect that choosing Now controlling for financial literacy should not have an impact on how fund information is interpreted across frames, but instead only affect measures of investments as we showed in the prior tables. It is also of interest to ask how framing interacts with both education and income. When we add an interaction for having received a Gain sheet and having post-secondary education, the odds ratio is significantly less than one for the interaction, and the interaction between financial literacy and a Gain sheet becomes insignificant. Interestingly, the coefficient on the interaction between information framing and financial literacy is stable across the two specifications, suggesting that financial literacy scores and educational attainment are sufficiently uncorrelated to effectively test their separate influences on the ranking of AFP choices. Our results suggest that education is a stronger determinant of how sensitive respondents are to viewing information in Gains rather than Losses. Last, we add yet another interaction term testing for a joint effect of higher income and receiving a gains sheet. Here, the new interaction term is not statistically significant and the reported odds ratio is near one.

\section{Conclusions and Discussion}

This paper examines the roles of financial literacy and impatience on retirement saving and investment behavior, using new data we have generated using the Chilean EPS. We measure financial literacy as the ability to understand basic concepts like inflation, compounding, and investment returns, and we measure impatience using a game designed to elicit preferences for 
current gratification versus future gain and being able to follow through with it. We find that the impatience measure strongly predicts respondents' self-reported retirement saving and health investments. Financial literacy is also associated with more retirement saving, but it is less closely associated with sensitivity to framing of investment information.

Our results should interest policymakers seeking to determine how to better shape the environment in which individuals undertake saving and investment choices. Our results imply that it may be useful to facilitate decision making, particularly among the less-educated, as well as to facilitate people committing to and carrying out long-term financial decisions. As individuals are being asked to exert more control over their own retirement accounts (e.g., 401(k)s) and other household investments, this raises a concern about whether consumers are capable of making optimal investment and saving decisions. Further, the development of evermore complex financial products probably makes it difficult for consumers to use these sensibly. What we have shown is that participant awareness of higher net-return funds can be greatly enhanced when information on fees is simplified in terms of likely gains from selecting higher net return funds. The impact of fund fee framing is largest for the least financially literate and the lowest-educated groups. By contrast, choices made by the financially well-informed tend to be less responsive to the information presentation, since those individuals tend to better understand the financial concepts necessary to translate annual percentage rates into costs and benefits. In the future, a field test of such policies would be the next step towards designing systems that level the playing field across socioeconomic groups and enable participants to commit to take actions now for greater gains later. 


\section{References:}

Abaluck, Jason and Jonathan Gruber (2009). "Choice Inconsistencies Among the Elderly: Evidence from Plan Choice in the Medicare Part D Program." NBER Working Papers 14759.

Arenas de Mesa, Alberto, David Bravo, Jere R. Behrman, Olivia S. Mitchell, and Petra E. Todd. (2008). "The Chilean Pension Reform Turns 25: Lessons from the Social Protection Survey." In Stephen Kay and Tapen Sinha. eds. Lessons from Pension Reform in the Americas, eds. Oxford: OUP 23-58.

Ashraf, Nava, Dean Karlan and Wesley Yin (2006). "Tying Odysseus to the Mast; Evidence from a Commitment Savings Product in the Philippines." The Quarterly Journal of Economics. 121(2): 635-672.

Ausubel, Lawrence M. (1991). “The Failure of Competition in the Credit Card Market." American Economic Review, 81(1): 50-81.

Behrman, Jere, Olivia S. Mitchell, Cindy Soo, and David Bravo. (2010). "Financial Literacy and Household Wealth Accumulation.” Wharton Pension Research Council Working Paper.

Benartzi, Shlomo, and Richard H. Thaler (2001). "Naïve Diversification Strategies in Defined Contribution Saving Plans.” American Economic Review, 91(1): 79-98.

Bravo, David, Jere Behrman, Olivia S. Mitchell, and Petra Todd (2004). Análisis y Principales Resultados: Primera Encuesta de Protección Social (Historia Laboral y Seguridad Social, 2002). www.proteccionsocial.cl/english/docs/AnalisisPrincipalesResultadosPrimeraEncuestaProteccionSocial.pdf

Bravo, David, Jere Behrman, Olivia S. Mitchell, and Petra Todd (2006). Encuesta de Protección Social 2004: Presentación General y Principales Resultados. www.proteccionsocial.cl/english/docs/Encuesta_Protección_Social\%2020041.pdf

Campbell, John (2006). “Household Finance.” Journal of Finance, August. 61: 1553-1604.

Choi, James J., David Laibson and Brigitte C. Madrian (2007). "\$100 Bills on the Sidewalk: Suboptimal Investment in 401(k) Plans." NBER Working Paper 11554.

Choi, James J., David Laibson and Brigitte C. Madrian (2006). "Why Does the Law of One Price Fail? An Experiment on Index Mutual Funds." NBER Working Paper 12261.

Cronqvist, Henrik, and Richard H. Thaler (2004). "Design Choices in Privatized Social-Security Systems: Learning from the Swedish Experience.” American Economic Review (Papers and Proceedings), 94(2): 424-428.

Duarte, Fabian and Justine S. Hastings, (2010). "Fettered Consumers and Sophisticated Firms: Evidence from Mexico’s Privatized Social Security Market.” Unpublished Manuscript, Yale University.

Hastings, Justine, Olivia S. Mitchell, and Eric Chyn. 2010. “Fees, Framing, and Financial Literacy in the Choice of Pension Manager.” Pension Research Council Working Paper. The Wharton School.

Hastings, Justine and Lydia Tejeda-Ashton (2008). "Financial Literacy, Information and Demand Elasticity: Survey and Experimental Evidence from Mexico. NBER Working Paper No. 14538.

Hilgert, Marianne A., Jeanne M. Hogarth, and Sondra G. Beverly (2003). "Household Financial Management: The Connection between Knowledge and Behavior.” Federal Reserve Bulletin, 89: 309-322. 
Lusardi, Annamaria and Olivia S. Mitchell (2010). "How Ordinary Consumers Make Complex Economic Decisions: Financial Literacy and Retirement Readiness." Journal of Consumer Affairs.

Lusardi, Annamaria and Olivia S. Mitchell. (2009). "Financial Literacy: Evidence and Implications for Financial Education.” Trends and Issues. TIAA-CREF Institute, 2009

Lusardi, Annamaria and Olivia S. Mitchell (2008). "Planning and Financial Literacy: How Do Women Fare?” American Economic Review (Papers and Proceedings), 98(2): 413-417

Lusardi, Annamaria and Olivia S. Mitchell (2007a). "Baby Boomer Retirement Security: The Roles of Planning, Financial Literacy, and Housing Wealth.” Journal of Monetary Economics 54: 205-224.

Lusardi, Annamaria and Olivia S. Mitchell (2007b). "Financial Literacy and Retirement Planning: New Evidence from the RAND American Life Panel.” NBER Working Paper.

Lusardi, Annamaria, Olivia S. Mitchell, and Vilsa Curto. 2010. "Financial Literacy among the Young: Evidence and Implications for Consumer Policy.” Journal of Consumer Affairs. (44, 2): 358-380.

Lusardi, Annamaria and Peter Tufano (2008). "Debt Literacy, Financial Experience and Overindebtedness." HBS Working Paper.

Kling, Jeffrey R., Sendhil Mullainathan, Eldar Shafir, Lee Vermeulen, and Marian V. Wrobel (2008). "Confusion and Choice in Medicare Drug Plan Selection." Unpublished Manuscript.

Madrian, Brigitte and Dennis F. Shea (2001). "The Power of Suggestion: Inertia in 401(k) Participation and Savings Behavior.” The Quarterly Journal of Economics, 116: 11491187.

Mitchell, Olivia S., Petra Todd, and David Bravo (2008). "Learning from the Chilean Experience: The Determinants of Pension Switching." In Annamaria Lusardi, Ed. Overcoming the Saving Slump: Making Financial Education and Saving Programs More Effective. University of Chicago Press: 301-323.

OECD Directorate for Financial and Enterprise Affairs. Nd. "Financial Education." www.oecd.org/department/0,3355,en_2649_15251491_1_1_1_1_1,00.html

President's Advisory Committee on Financial Literacy (PACFL) (2008). Annual Report to the President: Executive Summary. www.ustreas.gov/offices/domestic-finance/financial-institution/fineducation/council/exec_sum.pdf

Ponce-Rodriguez, Alejandro (2008). "Teaser Rate Offers in the Credit Card Market: Evidence from Mexico." Stanford University Working Paper.

Sirri, Erik and Peter Tufano. (1998). "Costly Search and Mutual Fund Flows." Journal of Finance, 53, 1589-1622. 


\section{Table 1. Financial Literacy and Other Sociodemographic Characteristics of EPS Respondents (2009)}

\begin{tabular}{cccccccc}
$\begin{array}{c}\text { Number of Correct } \\
\begin{array}{c}\text { Financial Literacy } \\
\text { Questions }\end{array}\end{array}$ & $\begin{array}{c}\text { Age } \\
\text { (Yrs) }\end{array}$ & Male (\%) & $\begin{array}{c}\text { More than } \\
\text { Secondary } \\
\text { Educ. (\%) }\end{array}$ & $\begin{array}{c}\text { Avg. Monthly } \\
\text { Income }^{1} \text { (CP \$) }\end{array}$ & $\begin{array}{c}\text { Any Saving } \\
\text { (\%) }\end{array}$ & $\begin{array}{c}\text { AFP } \\
\text { Member } \\
\text { (\%) }\end{array}$ & Obs. \\
\hline 0 & 57 & 42 & 11 & 177,730 & 15 & 47 & 3,551 \\
1 & 51 & 44 & 0 & 212,408 & 20 & 65 & 2,788 \\
2 & 48 & 49 & 0 & 264,283 & 26 & 72 & 2,781 \\
3 & 46 & 52 & 40 & 349,340 & 28 & 79 & 2,588 \\
4 & 45 & 58 & 52 & 398,306 & 30 & 83 & 1,792 \\
5 & 45 & 62 & 64 & 557,379 & 36 & 85 & 675 \\
6 & 45 & 75 & 85 & 932,039 & 31 & 87 & 68 \\
Total & 50 & 49 & 29 & 287,731 & 24 & 68 & 14,243 \\
\hline
\end{tabular}

Notes: ${ }^{1}$ Average monthly income calculation excludes those with zero income. ${ }^{2}$ Statistic created from Question D27 in the EPS. Interviewees have savings if they respond they have any of the following: (1) Savings for a Home (at a bank), (2) AVF Savings (Housing Fund Admin.), (3) Voluntary Pension Savings, (4) Account 2 AFP Savings, (5) Bank Savings Account, (6) Term Deposits, (7) Mutual Fund Investments, (8) Company Shares or Bonds, (9) Third Party Loans, (10) Other Savings (Cash, Dollars, "Polla”, etc.). 


\section{Table 2. Financial Literacy Responses and Respondent Characteristics of AFP Participants}

\begin{tabular}{lccccc} 
Financial Literacy Question & Age (Yrs) & Male (\%) & $\begin{array}{c}\text { More than } \\
\text { Secondary } \\
\text { Educ. (\%) }\end{array}$ & $\begin{array}{c}\text { Avg. Monthly } \\
\text { Income }^{1} \text { (CP \$) }\end{array}$ & $\begin{array}{c}\text { Any Saving } \\
\text { (\%) }\end{array}$ \\
\hline Chance of Disease & 43 & 58 & 48 & 397,895 & 31 \\
Lottery & 44 & 58 & 48 & 403,792 & 30 \\
Simple Interest & 44 & 56 & 46 & 386,233 & 32 \\
Compound Interest & 43 & 79 & 84 & 750,137 & 39 \\
Inflation & 45 & 59 & 50 & 427,395 & 32 \\
Risk Diversification & 44 & 56 & 43 & 377,870 & 31 \\
\hline
\end{tabular}

Notes: ${ }^{1}$ Average monthly income calculation excludes those with zero income. ${ }^{2}$ Statistic created from Question D27 in the EPS. Interviewees have savings if they respond they have any of the following: (1) Savings for a Home (at a bank), (2) AVF Savings (Housing Fund Admin.), (3) Voluntary Pension Savings, (4) Account 2 AFP Savings, (5) Bank Savings Account, (6) Term Deposits, (7) Mutual Fund Investments, (8) Company Shares or Bonds, (9) Third Party Loans, (10) Other Savings (Cash, Dollars, “Polla”, etc.). 


\section{Table 3: Summary Statistics for Investment Game Decisions}

\begin{tabular}{cccc} 
Offer Amount (CP \$) & Now (\%) & Later, No-Mail-in (\%) & Later, Mail-in (\%) \\
\hline 6,000 & 61.1 & 17.5 & 21.4 \\
6,500 & 58 & 16.1 & 25.9 \\
7,000 & 53.3 & 16.5 & 30.1 \\
7,500 & 51 & 16.7 & 32.3 \\
8,000 & 46.1 & 16.4 & 37.5 \\
Total & 53.9 & 16.7 & 29.5 \\
\hline Notes: Offer Amount is the amount offered to respondents for choosing to mail in their supplemental survey and \\
receive compensation at a later date. Now is the decision to receive 5000 pesos at the time of survey rather than a \\
higher amount later. Later, No-Mail-In are those who chose to receive more than 5000 pesos later but did not mail in \\
the supplemental survey before the offer expired. Later, Mail-In chose to receive more than 5000 pesos later, mailed \\
in the supplemental survey, and received this higher amount.
\end{tabular}


Table 4: Factors Affecting Investment Game Decision-making

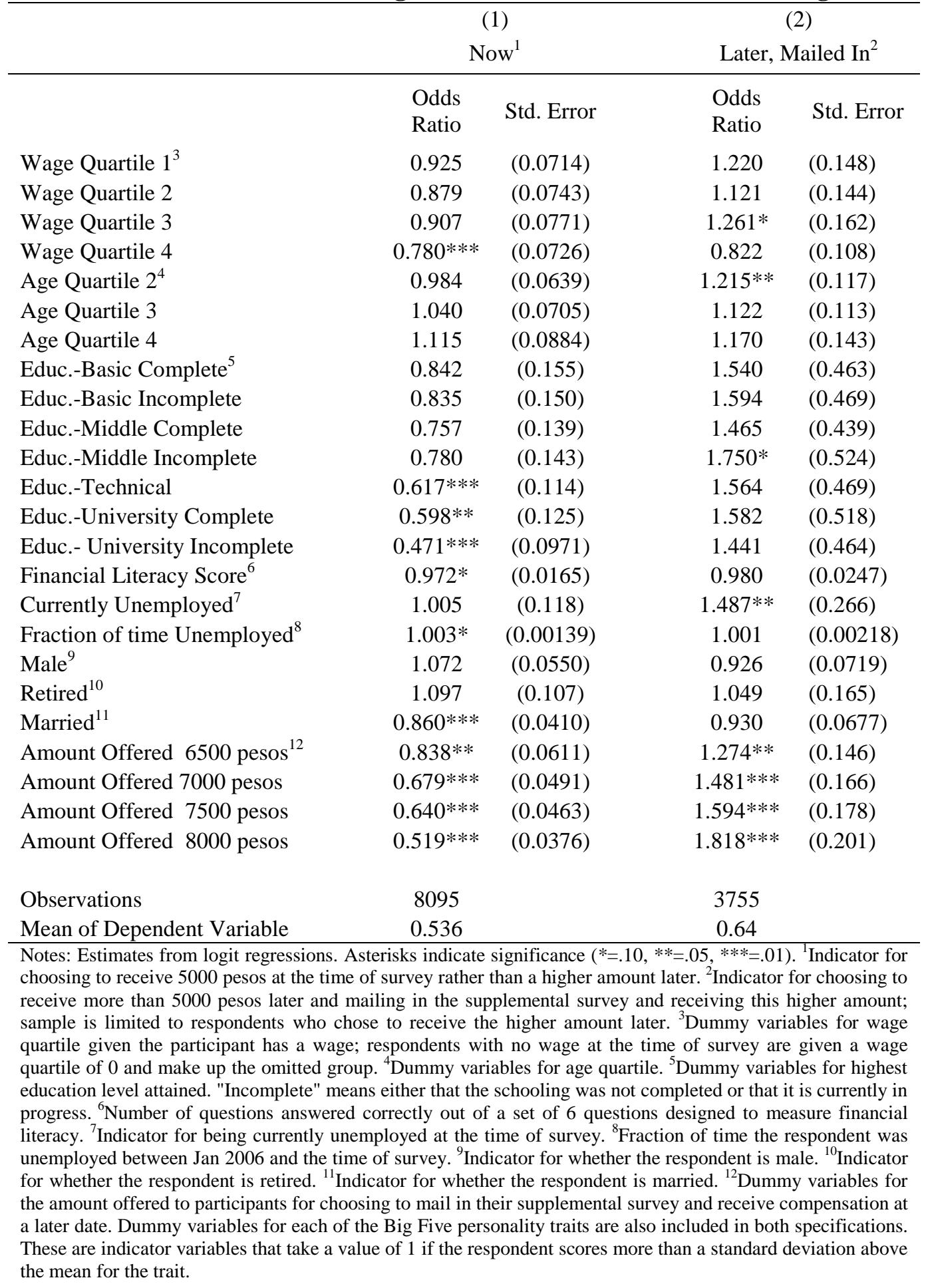




\section{Table 5: How Financial Literacy and Impatience Correlates with Any Voluntary Pension Saving and Total Saving}

\begin{tabular}{|c|c|c|c|c|}
\hline & \multicolumn{2}{|c|}{$\begin{array}{c}\text { (1) } \\
\text { Voluntary Pension }\end{array}$} & \multicolumn{2}{|c|}{$\begin{array}{c}\text { (2) } \\
\text { Total Savings }{ }^{2}\end{array}$} \\
\hline & Odds Ratio & $\begin{array}{l}\text { Std. } \\
\text { Error }\end{array}$ & Coefficient & $\begin{array}{l}\text { Std. } \\
\text { Error }\end{array}$ \\
\hline Now $^{3}$ & $0.759 *$ & $(0.124)$ & $-7832 * * *$ & (2765) \\
\hline Later, Mailed In $^{4}$ & 1.088 & $(0.180)$ & -1215 & (2951) \\
\hline Wage Quartile $1^{5}$ & $2.983 * * *$ & (1.157) & 3111 & (3507) \\
\hline Wage Quartile 2 & $5.572 * * *$ & (2.048) & 5227 & (3757) \\
\hline Wage Quartile 3 & $6.938 * * *$ & $(2.482)$ & $10901 * * *$ & (3704) \\
\hline Wage Quartile 4 & $15.11 * * *$ & $(5.330)$ & $13903^{* * *}$ & (3965) \\
\hline Age Quartile $2^{6}$ & 1.166 & $(0.186)$ & $-7140 * * *$ & (2709) \\
\hline Age Quartile 3 & $1.606^{* * *}$ & $(0.260)$ & $-5276 *$ & (2867) \\
\hline Age Quartile 4 & 0.674 & $(0.191)$ & $-17415^{* * *}$ & (3649) \\
\hline Educ.-Basic Complete $^{7}$ & 0.536 & $(0.574)$ & 6963 & (9629) \\
\hline Educ.-Basic Incomplete & 0.587 & $(0.622)$ & 2131 & $(9470)$ \\
\hline Educ.-Middle Complete & 1.734 & (1.785) & $16019 *$ & $(9542)$ \\
\hline Educ.-Middle Incomplete & 1.115 & (1.156) & 3387 & (9585) \\
\hline Educ.-Technical & 1.824 & (1.878) & 14908 & (9567) \\
\hline Educ.-University Complete & 2.389 & $(2.490)$ & $24911 * *$ & (10251) \\
\hline Educ.- University Incomplete & 2.189 & $(2.282)$ & 13085 & (10267) \\
\hline Financial Literacy Score ${ }^{8}$ & 1.035 & $(0.0460)$ & $2929 * * *$ & (736.7) \\
\hline Currently Unemployed & $5.686 * * *$ & $(2.519)$ & 631.4 & (5165) \\
\hline Fraction of time Unemployed ${ }^{9}$ & $0.992 *$ & $(0.00475)$ & -2.847 & $(60.18)$ \\
\hline Male & 0.965 & $(0.130)$ & $-3922 *$ & (2254) \\
\hline Retired & 0.829 & $(0.663)$ & 1459 & (4948) \\
\hline Married & 1.082 & $(0.143)$ & 843.3 & (2113) \\
\hline Observations & 8095 & & 7675 & \\
\hline Mean of Dependent Variable & 0.037 & & 897.429 & \\
\hline
\end{tabular}

Notes: Estimates from a logit regression for having made voluntary pension contributions and a tobit regression for total savings. Asterisks indicate significance $(*=.10, * *=.05, * * *=.01)$. ${ }^{1}$ Indicator for having made voluntary pension savings between Jan. 2006 and the time of survey. ${ }^{2}$ Total amount of savings and investments in 1000s of pesos. ${ }^{3}$ Indicator for choosing to receive 5000 pesos at the time of survey rather than a higher amount later. ${ }^{4}$ Indicator for choosing to receive more than 5000 pesos later and mailing in the supplemental survey and receiving this higher amount. ${ }^{5}$ Dummy variables for wage quartile given the participant has a wage; respondents with no wage at the time of survey make up the omitted group. ${ }^{6}$ Dummy variables for age quartile. ${ }^{7}$ Dummy variables for highest education level attained. ${ }^{8}$ Number of questions answered correctly out of a set of 6 questions designed to measure financial literacy. ${ }^{9}$ Fraction of time the respondent was unemployed between Jan 2006 and the time of survey. Dummy variables for the amount offered to participants for choosing the Later option and dummy variables for scoring over a std. deviation above the mean for a Big Five personality trait are also included in all specifications. 
Table 6: How Investment Game Behaviors Covary with Preventative Health Behaviors

\begin{tabular}{|c|c|c|c|c|c|c|c|c|c|c|}
\hline & \multicolumn{2}{|c|}{$\begin{array}{c}(1) \\
\text { Pap Smear }{ }^{1}\end{array}$} & \multicolumn{2}{|c|}{$\begin{array}{c}(2) \\
\text { Breast Examination }^{2}\end{array}$} & \multicolumn{2}{|c|}{$\begin{array}{c}\text { (3) } \\
\text { Prostate Exam } \\
\text { Pet }\end{array}$} & \multicolumn{2}{|c|}{$\begin{array}{c}\text { (4) } \\
\text { General Consultation }^{4} \\
\end{array}$} & \multicolumn{2}{|c|}{$\begin{array}{c}\text { (5) } \\
\text { Exercise }^{5}\end{array}$} \\
\hline & Odds & Std. & Odds & Std. & Odds & Std. & Odds & & Odds & Std. \\
\hline & Ratio & Error & Ratio & Error & Ratio & Error & Ratio & Std. Error & Ratio & Error \\
\hline Now $^{6}$ & $0.651 * * *$ & $(0.107)$ & $0.783 * *$ & $(0.0782)$ & 1.016 & $(0.153)$ & 1.014 & $(0.0659)$ & 0.948 & $(0.0786)$ \\
\hline Later, Mailed In $^{7}$ & 0.814 & $(0.144)$ & 0.961 & $(0.103)$ & 0.950 & $(0.160)$ & $1.164^{* *}$ & $(0.0819)$ & 0.972 & $(0.0872)$ \\
\hline Wage Quartile $1^{8}$ & 0.938 & $(0.171)$ & 0.886 & $(0.0899)$ & $0.589 * *$ & $(0.132)$ & $0.846^{* *}$ & $(0.0655)$ & 1.011 & $(0.110)$ \\
\hline Wage Quartile 2 & $0.656 * *$ & $(0.128)$ & 1.150 & $(0.139)$ & $0.653 *$ & $(0.149)$ & $0.769 * * *$ & $(0.0660)$ & 0.944 & $(0.108)$ \\
\hline Wage Quartile 3 & 0.815 & $(0.166)$ & 0.873 & $(0.115)$ & 0.839 & $(0.181)$ & 0.911 & $(0.0780)$ & 0.878 & $(0.0987)$ \\
\hline Wage Quartile 4 & 1.092 & $(0.258)$ & 0.916 & $(0.141)$ & $1.731^{* *}$ & $(0.384)$ & 0.860 & $(0.0804)$ & 0.933 & (0.109) \\
\hline Age Quartile $2^{9}$ & 1.275 & $(0.217)$ & $1.332 * * *$ & $(0.118)$ & & & 1.059 & $(0.0703)$ & $0.701^{* * *}$ & $(0.0568)$ \\
\hline Age Quartile 3 & & & 1.149 & $(0.108)$ & $0.521 * * *$ & $(0.0680)$ & $1.312 * * *$ & $(0.0903)$ & $0.636 * * *$ & $(0.0553)$ \\
\hline Age Quartile 4 & & & 1.377 & $(0.353)$ & & & $1.767 * * *$ & $(0.141)$ & $0.555^{* * *}$ & $(0.0598)$ \\
\hline Educ.-Basic Complete $^{10}$ & & & $2.633 *$ & $(1.302)$ & 0.917 & $(0.282)$ & 1.061 & $(0.188)$ & $3.519 * * *$ & $(1.513)$ \\
\hline Educ.-Basic Incomplete & 0.898 & $(0.282)$ & 2.146 & $(1.054)$ & 0.675 & $(0.201)$ & 1.075 & $(0.186)$ & $2.865 * *$ & $(1.225)$ \\
\hline Educ.-Middle Complete & 0.913 & $(0.220)$ & $2.599 *$ & $(1.272)$ & 1.594 & $(0.509)$ & 1.040 & $(0.184)$ & $4.675^{* * *}$ & (1.998) \\
\hline Educ.-Middle Incomplete & 1.222 & $(0.344)$ & $3.025 * *$ & $(1.486)$ & 0.816 & $(0.256)$ & 1.064 & $(0.188)$ & $4.002 * * *$ & $(1.713)$ \\
\hline Educ.-Technical & 1.096 & $(0.260)$ & $2.937 * *$ & (1.439) & 1.099 & $(0.355)$ & 1.119 & $(0.198)$ & $5.281^{* * *}$ & $(2.257)$ \\
\hline Educ.-University Complete & 0.823 & $(0.249)$ & $3.087 * *$ & $(1.582)$ & $2.631 * *$ & $(1.048)$ & 1.191 & $(0.238)$ & $8.210 * * *$ & (3.599) \\
\hline Educ.- University Incomplete & 0.824 & $(0.255)$ & $2.889 * *$ & $(1.475)$ & $1.954^{*}$ & $(0.750)$ & $1.403^{*}$ & $(0.278)$ & $7.441^{* * *}$ & $(3.255)$ \\
\hline Currently Unemployed & $0.517 * *$ & $(0.133)$ & 0.901 & $(0.153)$ & 1.029 & $(0.317)$ & 0.866 & $(0.102)$ & 0.819 & $(0.126)$ \\
\hline Fraction of time Unemployed $^{11}$ & 1.005 & $(0.00291)$ & 1.001 & $(0.00192)$ & 0.994 & $(0.0040)$ & 1.000 & $(0.0014)$ & $1.003 *$ & $(0.0018)$ \\
\hline Male & & & & & & & $0.527 * * *$ & $(0.0273)$ & $2.287 * * *$ & $(0.155)$ \\
\hline Retired & & & $4.050 * *$ & $(2.655)$ & $1.499 * *$ & $(0.271)$ & $1.213^{* *}$ & $(0.118)$ & 0.880 & $(0.131)$ \\
\hline Married & $1.647^{* * *}$ & $(0.209)$ & 1.125 & $(0.0832)$ & $1.588^{* * *}$ & $(0.200)$ & $1.201 * * *$ & $(0.0580)$ & 0.956 & $(0.0607)$ \\
\hline Observations & 1312 & & 3279 & & 1714 & & 8082 & & 8095 & \\
\hline Mean of Dependent Variable & 0.616 & & 0.507 & & 0.373 & & 0.458 & & 0.178 & \\
\hline
\end{tabular}

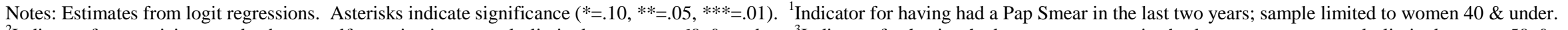

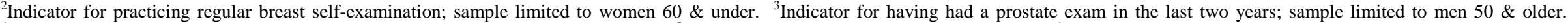

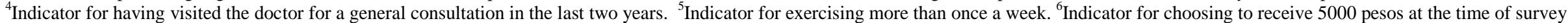

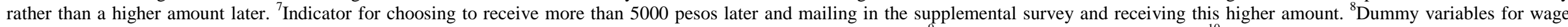

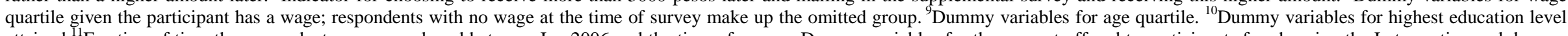

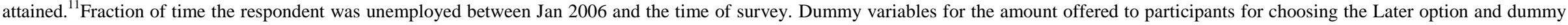
variables for scoring over a std. deviation above the mean for a Big Five personality trait are also included in all specifications. 
Table 7: How Investment Game Behaviors Covary with Overweight

(1)

Overweight ${ }^{1}$

\begin{tabular}{|c|c|c|c|c|c|c|}
\hline & $\begin{array}{l}\text { Odds } \\
\text { Ratio }\end{array}$ & Std. Error & Odds Ratio & Std. Error & Odds Ratio & Std. Error \\
\hline Now $^{2}$ & 0.910 & $(0.0626)$ & 1.018 & $(0.101)$ & $0.800 * *$ & $(0.0783)$ \\
\hline Wage Quartile $1^{4}$ & 1.059 & $(0.0886)$ & $1.326 *$ & $(0.218)$ & 1.098 & $(0.113)$ \\
\hline Wage Quartile 2 & 0.926 & $(0.0830)$ & 1.117 & $(0.178)$ & 1.081 & $(0.133)$ \\
\hline Wage Quartile 3 & 0.956 & $(0.0860)$ & 1.256 & $(0.197)$ & 0.821 & $(0.108)$ \\
\hline Age Quartile $2^{5}$ & $1.381^{* * *}$ & $(0.0936)$ & 1.176 & $(0.121)$ & $1.585^{* * *}$ & $(0.147)$ \\
\hline Age Quartile 3 & $1.508 * * *$ & $(0.108)$ & 1.147 & $(0.124)$ & $1.853 * * *$ & $(0.183)$ \\
\hline Age Quartile 4 & $1.354 * * *$ & $(0.114)$ & 1.045 & $(0.132)$ & $1.681^{* * *}$ & $(0.198)$ \\
\hline Educ.-Basic Complete $^{6}$ & 0.944 & $(0.198)$ & 1.059 & $(0.305)$ & 0.816 & $(0.265)$ \\
\hline Educ.-Basic Incomplete & 0.823 & $(0.168)$ & 0.982 & $(0.278)$ & 0.645 & $(0.204)$ \\
\hline Educ.- University Incomplete & $0.524 * * *$ & $(0.119)$ & 0.958 & $(0.300)$ & $0.288 * * *$ & $(0.100)$ \\
\hline Currently Unemployed & 0.887 & $(0.109)$ & 1.046 & $(0.205)$ & 0.949 & $(0.166)$ \\
\hline Fraction of time Unemployed ${ }^{7}$ & 1.000 & $(0.00144)$ & 0.998 & $(0.00223)$ & 1.000 & $(0.00198)$ \\
\hline Male & $1.093^{*}$ & $(0.0590)$ & & & & \\
\hline Retired & $0.827 *$ & $(0.0870)$ & 1.100 & $(0.187)$ & $0.780 *$ & $(0.117)$ \\
\hline Married & $1.392^{* * *}$ & $(0.0704)$ & $1.639 * * *$ & $(0.126)$ & $1.295^{* * *}$ & $(0.0913)$ \\
\hline Observations & 7579 & & 3620 & & 3959 & \\
\hline Mean of Overweight & 0.627 & & 0.644 & & 0.611 & \\
\hline
\end{tabular}

Notes: Estimates from logit regressions. Asterisks indicate significance $(*=.10, * *=.05, * * *=.01) .{ }^{1}$ Indicator for a Body Mass Index (BMI) in the range classified as either overweight or obese; BMI is calculated from respondent reported weight and height. ${ }^{2}$ Indicator for choosing to receive 5000 pesos at the time of survey rather than a higher amount later. ${ }^{3}$ Indicator for choosing to receive more than 5000 pesos later and mailing in the supplemental survey and receiving this higher amount. ${ }^{4}$ Dummy variables for wage quartile given the participant has a wage; respondents with no wage at the time of survey make up the omitted group. ${ }^{5}$ Dummy variables for age quartile. ${ }^{6}$ Dummy variables for highest education level attained. ${ }^{7}$ Fraction of time the respondent was unemployed between Jan 2006 and the time of survey. Dummy variables for the amount offered to participants for choosing the Later option and dummy variables for scoring over a std. deviation above the mean for a Big Five personality trait are also included in all specifications. 


\section{Table 8. Factors Associated with Respondent Ranking Lowest-Cost AFP as Best}

(AFP Participants)

\begin{tabular}{cccccccc}
$\begin{array}{c}\text { Ranked } \\
\text { Lowest-Cost } \\
\text { AFP Best }\end{array}$ & $\begin{array}{c}\text { Saw } \\
\text { Gains } \\
\text { Sheet } \\
(\%)\end{array}$ & $\begin{array}{c}\text { Age } \\
\text { (Yrs) }\end{array}$ & $\begin{array}{c}\text { Male } \\
(\%)\end{array}$ & $\begin{array}{c}\text { More than } \\
\text { Secondary Educ. } \\
(\%)\end{array}$ & $\begin{array}{c}\text { Avg. Monthly } \\
\text { Income }^{1} \text { (CP\$) }\end{array}$ & $\begin{array}{c}\text { Any } \\
\text { Savings }^{2} \\
(\%)\end{array}$ & Obs. $^{3}$ \\
\hline No & 48 & 45 & 54 & 32 & 297,491 & 28 & 4,923 \\
Yes & 53 & 46 & 54 & 41 & 371,975 & 29 & 3,691 \\
Total & 50 & 45 & 54 & 36 & 329,873 & 28 & 8,614 \\
\hline
\end{tabular}

Notes: ${ }^{1}$ Average monthly income calculation excludes those with zero income. ${ }^{2}$ Statistic created from question D27 in the EPS. Interviewees have savings if they respond that they have any of the following: (1) Savings for a Home (at a bank), (2) AVF Savings (Housing Fund Admin.), (3) Voluntary Pension Savings, (4) Account 2 AFP Savings, (5) Bank Savings Account, (6) Term Deposits, (7) Mutual Fund Investments, (8) Company Shares or Bonds, (9) Third Party Loans, (10) Other Savings (Cash, Dollars, "Polla”, etc.). ${ }^{3}$ Total is less than 9,671 (all self-identified AFP holders) because some interviewees do not receive the experiment. 


\section{Table 9. Logit Analysis of Factors Associated with Respondent Ranking Lowest-Cost AFP as Best (Odds Ratios Reported)}

\begin{tabular}{|c|c|c|c|c|c|}
\hline Saw Gains Sheet & $\begin{array}{c}1.202^{* * *} \\
(0.076)\end{array}$ & $\begin{array}{c}1.461^{* * * *} \\
(0.172)\end{array}$ & $\begin{array}{c}1.419 * * * \\
(0.192)\end{array}$ & $\begin{array}{c}1.535^{* * *} \\
(0.213)\end{array}$ & $\begin{array}{c}1.679 * * * \\
(0.251)\end{array}$ \\
\hline Age & $\begin{array}{c}1.087 * * * \\
(0.019)\end{array}$ & $\begin{array}{c}1.088^{* * *} \\
(0.019)\end{array}$ & $\begin{array}{c}1.088 * * * \\
(0.019)\end{array}$ & $\begin{array}{c}1.087^{* * * *} \\
(0.019)\end{array}$ & $\begin{array}{c}1.087^{* * * *} \\
(0.019)\end{array}$ \\
\hline Age-squared & $\begin{array}{c}0.999 * * * \\
(0.0002)\end{array}$ & $\begin{array}{c}0.999 * * * \\
(0.0002)\end{array}$ & $\begin{array}{c}0.999 * * * \\
(0.0002)\end{array}$ & $\begin{array}{c}0.999 * * * \\
(0.0002)\end{array}$ & $\begin{array}{c}0.999 * * * \\
(0.0002)\end{array}$ \\
\hline Male & $\begin{array}{c}0.957 \\
(0.065)\end{array}$ & $\begin{array}{c}0.956 \\
(0.065)\end{array}$ & $\begin{array}{c}0.957 \\
(0.065)\end{array}$ & $\begin{array}{c}0.958 \\
(0.065)\end{array}$ & $\begin{array}{c}0.960 \\
(0.065)\end{array}$ \\
\hline Married & $\begin{array}{c}0.946 \\
(0.064)\end{array}$ & $\begin{array}{c}0.946 \\
(0.064)\end{array}$ & $\begin{array}{c}0.946 \\
(0.064)\end{array}$ & $\begin{array}{c}0.948 \\
(0.064)\end{array}$ & $\begin{array}{c}0.947 \\
(0.064)\end{array}$ \\
\hline At least 1 type of Savings ${ }^{1}$ & $\begin{array}{l}0.887 * \\
(0.063)\end{array}$ & $\begin{array}{l}0.883^{*} \\
(0.062)\end{array}$ & $\begin{array}{l}0.884^{*} \\
(0.063)\end{array}$ & $\begin{array}{l}0.881^{*} \\
(0.062)\end{array}$ & $\begin{array}{l}0.882 * \\
(0.062)\end{array}$ \\
\hline Financial Literacy Score ${ }^{2}$ & $\begin{array}{c}1.203^{* * *} \\
(0.027)\end{array}$ & $\begin{array}{c}1.253 * * * \\
(0.039)\end{array}$ & $\begin{array}{c}1.253 * * * \\
(0.039)\end{array}$ & $\begin{array}{c}1.231 * * * \\
(0.039)\end{array}$ & $\begin{array}{c}1.224 * * * \\
(0.039)\end{array}$ \\
\hline Now $^{3}$ & $\begin{array}{c}0.925 \\
(0.059)\end{array}$ & $\begin{array}{c}0.925 \\
(0.059)\end{array}$ & $\begin{array}{c}0.900 \\
(0.081)\end{array}$ & $\begin{array}{c}0.911 \\
(0.082)\end{array}$ & $\begin{array}{c}0.909 \\
(0.082)\end{array}$ \\
\hline$>$ Secondary Schooling & $\begin{array}{c}1.255^{* * *} \\
(0.090)\end{array}$ & $\begin{array}{c}1.256 * * * \\
(0.090)\end{array}$ & $\begin{array}{c}1.256 * * * \\
(0.090)\end{array}$ & $\begin{array}{c}1.503 * * * \\
(0.148)\end{array}$ & $\begin{array}{c}1.466 * * * \\
(0.146)\end{array}$ \\
\hline Above Median Income & $\begin{array}{l}1.145^{*} \\
(0.082)\end{array}$ & $\begin{array}{l}1.146 * \\
(0.082)\end{array}$ & $\begin{array}{l}1.147 * \\
(0.082)\end{array}$ & $\begin{array}{l}1.149 * \\
(0.082)\end{array}$ & $\begin{array}{c}1.285^{* *} \\
(0.129)\end{array}$ \\
\hline Financial Literacy * Saw Gains Sheet & & $\begin{array}{c}0.920 * * \\
(0.039)\end{array}$ & $\begin{array}{l}0.921^{*} \\
(0.039)\end{array}$ & $\begin{array}{c}0.954 \\
(0.042)\end{array}$ & $\begin{array}{c}0.965 \\
(0.043)\end{array}$ \\
\hline Chose Now * Saw Gains Sheet & & & $\begin{array}{l}1.057 \\
(0.134)\end{array}$ & $\begin{array}{c}1.031 \\
(0.131)\end{array}$ & $\begin{array}{c}1.031 \\
(0.131)\end{array}$ \\
\hline$>$ Secondary Schooling * Saw Gains Sheet & & & & $\begin{array}{c}0.699 * * * \\
(0.094)\end{array}$ & $\begin{array}{c}0.737 * * \\
(0.102)\end{array}$ \\
\hline Above Median Income * Saw Gains Sheet & & & & & $\begin{array}{c}0.801 \\
(0.111)\end{array}$ \\
\hline Observations $^{4}$ & 4282 & 4282 & 4282 & 4282 & 4282 \\
\hline
\end{tabular}

Notes: Standard errors in parentheses. Asterisks indicate significance $\left(*=.10,{ }^{* *}=.05,{ }^{* * *}=.01\right) .{ }^{1}$ Indicator created from Question D27 in the EPS. Interviewees have savings if they respond they have any of the following: (1) Savings for a Home (at a bank), (2) AVF Savings (Housing Fund Admin.), (3) Voluntary Pension Savings, (4) Account 2 AFP Savings, (5) Bank Savings Account, (6) Term Deposits, (7) Mutual Fund Investments, (8) Company Shares or Bonds, (9) Third Party Loans, (10) Other Savings (Cash, Dollars, "Polla”, etc.). ${ }^{2}$ Number of questions answered correctly out of a set of 6 questions designed to measure financial literacy. ${ }^{3}$ Indicator for choosing to receive 5000 pesos at the time of survey rather than a higher amount later. ${ }^{4}$ Observations are only for individuals who have all demographic responses nonmissing and are AFP members that received both experiments. 


\section{APPENDIX \\ Example Sheets from Fee Framing Experiment}

\section{Example 1: Fees framed as a loss versus the AFP with best net returns}

\section{¿Conoce la rentabilidad de $\underline{\text { u }}$ AFP?}

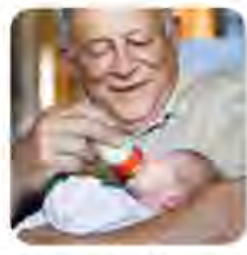

Suponga que su mejor amigo, Juan, está considerando cuál AFP elegir. Juan le ha pedido su consejo sobre cómo hacer su elección. Usted tiene un cuadro con información oficial que indica la diferencia entre los montos en pesos entre cada AFP y la AFP que obtuvo la mayor rentabilidad para una persona como usted después de 1 año de cotizaciones. Este cuadro es útil para elegir una AFP que probablemente le dará ta mayor cantidad de dinero

De acuerdo a la información presentada en el siguiente cuadro y a su conocimiento actual sobre las AFP, indique, en orden de importancia, las TRES MEJORES AFP que le recomendaria a su amigo Juan. En la casilla en blanco a la izquierda del nombre de la AFP, escriba el número 1 para la mejor opción, el nùmero 2 para la segunda mejor opción, y el número 3 para la tercera mejor opción.

\begin{tabular}{|l|c|c|}
\hline $\begin{array}{c}\text { Escriba } \\
1,203\end{array}$ & AFP & $\begin{array}{c}\text { Diferencia* } \\
\text { en pesas }\end{array}$ \\
\hline & CAPITAL & $-\$ 246.099$ \\
\hline & CUPRUM & $-\$ 125.606$ \\
\hline & HABITAT & $\$ 0$ \\
\hline & PLANVITAL & $-\$ 1.337 .026$ \\
\hline & PROVIDA & $-\$ 418.246$ \\
\hline
\end{tabular}

\section{¿Cómo se puede contactar con una AFP? Es fácil.}

Usted sólo tiene que llamar a la AFP que le gustaria contactar y ellos lo pueden ayudar con la información que necesite. A continuación se presentan los números de teléfono y las páginas web de las AFPs.

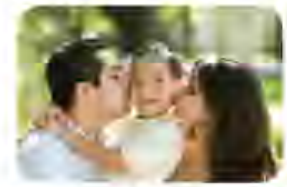

\begin{tabular}{|c|c|c|}
\hline AFP Capital (Bansander/Santa Maria) & http://www.ingcapital.cl/ & 6002520464 \\
\hline AFP Cuprum & http://www.cuprum.cl/webcuprum/ & 6002287786 \\
\hline AFP Habitat & http://Www.afphabitat.ct/Afiliados/Default.asp & 6002202000 \\
\hline AFP Planvital & http://www.planvital.cl/webplanvital/ & 6004854444 \\
\hline AFP Provida & http://www.bbvaprovida.ct/Website/default.âsp & 6002010150 \\
\hline
\end{tabular}




\section{Example 2: Fees framed as a gain in account value}

\section{¿Conoce la rentabilidad de su AFP?}

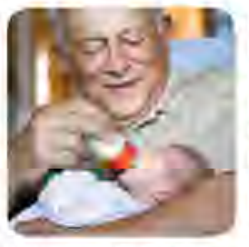

Suponga que su mejor amigo, Juan, está considerando cuál AFP elegir. Juan le ha pedido su consejo sobre cómo hacer su elección. Usted tiene un cuadro con información oficial que indica el monto en pesos que una persona como usted obtendría después de 1 año de cotizaciones en cada AFP. Este cuadro es útil para elegir una AFP que probablemente le dará la mayor cantidad de dinero para su pensión.

De acuerdo a la información presentada en el siguiente cuadro y a su conocimiento actual sobre las AFP, indique, en orden de importancia, las TRES MEJORES AFP que le recomendaria a su amigo Juan. En la casilla en blanco a la izquierda del nombre de la AFP, escriba el nùmero 1 para la mejor opción, el número 2 para la segunda mejor opción, yel número 3 para la tercera mejor opción.

\begin{tabular}{|l|c|c|}
\hline $\begin{array}{c}\text { Escriba } \\
1,203\end{array}$ & AFP & $\begin{array}{c}\text { Monto* } \\
\text { en pesos }\end{array}$ \\
\hline & CAPITAL & $\$ 5.199 .730$ \\
\hline & CUPRUM & $\$ 5.247 .133$ \\
\hline & HABITAT & $\$ 5.296 .548$ \\
\hline & PLANVITAL & $\$ 4.770 .546$ \\
\hline & PROVIDA & $\$ 5.132 .005$ \\
\hline
\end{tabular}

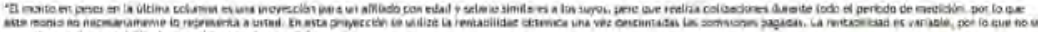

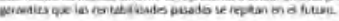

¿Cómo se puede contactar con una AFP? Es fácil.

Usted sólo tiene que llamar a la AFP que le gustaria contactar y ellos lo pueden ayudar con la información que necesite. A continuación se presentan los números de teléfono y las páginas web de las AFPs.

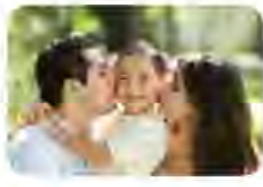

\begin{tabular}{|c|c|c|}
\hline AFP Capital (Bansander/Santa Maria) & http://wmw.ingcapital.cl/ & 6002520464 \\
\hline AFP Cuprum & http://www.cuprum.cl/webcuprum/ & 6002287786 \\
\hline AFP Habitat & http:///mww.afphabitat,cl/Afiliados/Default.asp & 6002202000 \\
\hline AFP Planvital & http://www.planvital.cl/webplanvital/ & 6004854444 \\
\hline AFP Pravida & http://www.bbvaprovida.cl/Website/default.asp & 6002010150 \\
\hline
\end{tabular}

